\section{The Least Weasel}

(From the Family Herald and Weekly Star)

By Austin W. Cameron

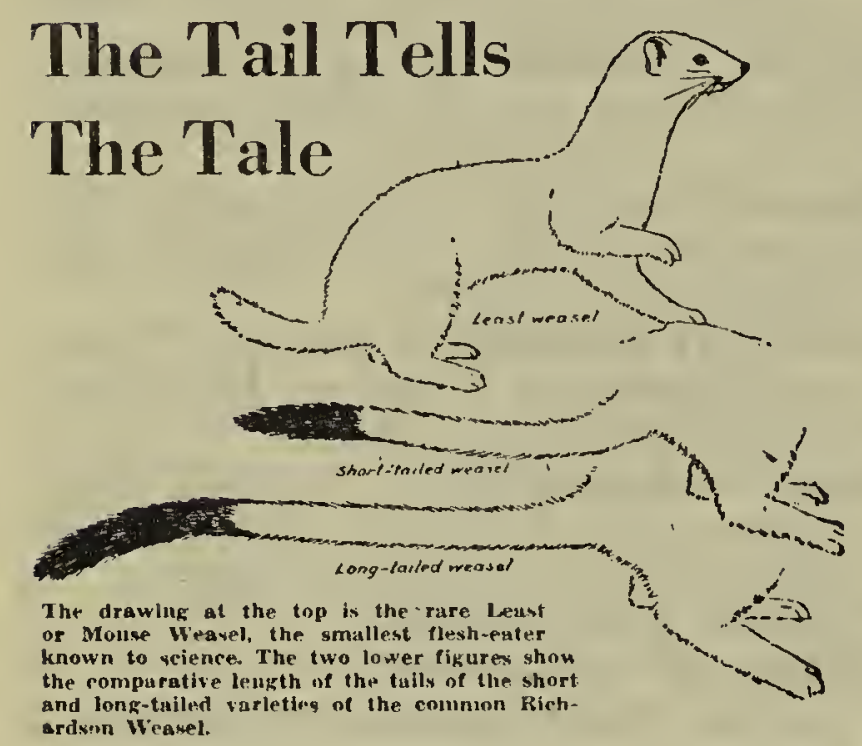

$\mathbf{A}^{\mathrm{L}}$ LMOST any farm trapper may capture the rare Least Weasel without realizing it, particularly if he does not examine his catch with any more than the usual amount of care. In the past trappers have discarded specimens of this animal in the belief that they were merely young of the familiar Richardson Weasel. Probably were all trappers aware of the existence of this tiny species it would be found to be less rare than is now supposed.

The Least or Mouse Weasel (Mustela rixosa) is not only the pigmy of its tribe, but it also bears the distinction of being the smallest flesh-eater known to science. A full grown male is scarcely nine inches in total length and actually weighs less than many of the larger species of mice. It may be readily distinguished by a very short tail that lacks the familiar black tip of the larger members of its tribe.

Like all weasels, this species changes its coat to suit the season. In summer its plain brown attire renders it inconspicuous as it siinks among dead grasses and brush piles or along a stone wall, and in winter its immaculate white coat blends perfectly against the snow.

The life history of so rare a mammal is very imperfectly known, but there is no reason to suppose that it is less courageous or bloodthirsty than other weasels. Because of its small size it probably lives chiefly on mice and it therefore should be an asset to any farm where it takes up residence. It must be the arch-enemy of mice where it does occur as it can follow them into the deepest recesses of their burrows.

The Least Weasel has been recorded in every province and territory of Canada except the Maritimes and Newfoundland, although biologists know of no reason why it should not occur on the mainland of Eastern Canada. In all probability it does occur there and some observant trapper in the area will discover one sooner or later. A specimen of this rarity from any part of Canada is enough to create a sensation in natural history circles.

\section{How Prevalent are They? \\ Cliff Shaw}

I HAVE always been under the impression that the Least Weasel are seldom seen and are rather scarce, yet I have seen six specimens. of these animals from the Yorkton district in the past month. Four of these specimens were taken by Ralph Meays, who farms five and a half miles northwest of Willowbrook. These were caught the week preceding and the week following Christmas. They were taken at four stone piles within a radius of four miles. Three of these specimens were sent to Mr. Fred Bard, director of the Provincial Museum, for positive identification. Mr. Meays tells me that in trapping weasels for the past several years he has caught one. but never more of this species each season.

(Mr. Bard, who examined some of these weasels, informs us that the Least Weasel is far more prevalent throughout the province than has usually been suspected. It cannot be considered as rare.-Ed.) 